\title{
FLUORESCENCE CHARACTERISTICS AND PHOTOINHIBITION IN SAPLINGS OF MANWOOD ON CLEAR DAYS AND UNDER OVERCAST CONDITIONS
}

\author{
Daniela Pereira Dias; Ricardo Antonio Marenco ${ }^{2 *}$ \\ ${ }_{2}^{1}$ INPA - Programa de Pós-Graduação em Ciências de Florestas Tropicais. \\ INPA - Coordenação de Pesquisas em Silvicultura Tropical, Av. André Araújo, 1756, C.P. 478 - $69011-970$ - \\ Manaus, AM - Brasil. \\ *Corresponding author <rmarenco@inpa.gov.br>
}

ABSTRACT: High irradiance may reduce the productivity of tropical plants by exacerbating photoinhibition of photosynthesis, particularly in the case of shade-adapted plants. The aim of this study was to determine the effect of cloud cover on the fluorescence characteristics and photoinhibition on saplings of manwood (Minquartia guianensis Aubl.). Three-year-old saplings were exposed to full irradiance either on clear days (10, 45 and $90 \mathrm{~min})$ or under overcast conditions (120, 180, and 420 min). Changes in the population of functional photosystem II (PSII), the initial $\left(\mathrm{F}_{\mathrm{o}}\right)$ and maximum fluorescences $\left(\mathrm{F}_{\mathrm{m}}\right)$, and the $\mathrm{F}_{\mathrm{v}} / \mathrm{F}_{\mathrm{m}}$ ratio (maximum potential quantum yield of PSII) were monitored after plant exposure to full irradiance and during recovery (within $48 \mathrm{~h}$ ) at low light intensity. Although photoinhibition of PSII $\left(\mathrm{F}_{\mathrm{v}} / \mathrm{F}_{\mathrm{m}}\right)$ was determined by the number of photons reaching the leaf surface (photon fluence), cloudiness tended to reduce the photoinhibitory effect of irradiance. $F_{0}$ increased with fluence on cloudy days and was unaffected by irradiance on clear days, except for a sharp rise during the first 10 min of exposure to full sunlight. For a given photon fluence, $\mathrm{F}_{\mathrm{m}}$ was lower on clear days. Recovery from photoinhibition was similar in both light environments. Although photon fluence is the preponderant factor determining the extent of photoinhibition, cloudiness might alleviate the photoinhibitory effect of irradiance.

Key words: Amazonia, functional photosystem II, initial fluorescence, light quality, photon fluence

\section{CARACTERÍSTICAS DA FLUORESCÊNCIA E FOTOINIBIÇÃO EM ARVORETAS DE ACARIQUARAEM DIAS NUBLADOS E ENSOLARADOS}

\begin{abstract}
RESUMO: Alta irradiância pode reduzir a produtividade de plantas tropicais por intensificar a fotoinibição da fotossíntese, particularmente em plantas adaptadas à sombra. O objetivo deste trabalho foi determinar o efeito da nebulosidade nas características da fluorescência e na fotoinibição em arvoretas de acariquara (Minquartia guianensis Aubl.). Plantas jovens de três anos de idade foram expostas à irradiância em dias ensolarados (10, 45 e $90 \mathrm{~min}$ ) ou nublados (120, 180 e $420 \mathrm{~min}$ ). Foram monitoradas mudanças na população de fotossistemas II (FSII) funcionais, na fluorescência inicial $\left(\mathrm{F}_{\mathrm{o}}\right)$ e máxima $\left(\mathrm{F}_{\mathrm{m}}\right)$ e na relação $\mathrm{F}_{\mathrm{v}} / \mathrm{F}_{\mathrm{m}}$ (rendimento quântico potencial do FSII), antes da exposição das plantas à irradiância e durante a recuperação (até 48 h) sob baixa intensidade luminosa. Apesar de a fotoinibição $\left(\mathrm{F}_{\mathrm{v}} / \mathrm{F}_{\mathrm{m}}\right)$ ser determinada pelo número de fótons incidentes na superfície da folha (fluência), houve tendência de a nebulosidade reduzir o efeito da irradiância na fotoinibição. $\mathrm{F}_{\mathrm{o}}$ aumentou com a fluência em dias nublados, mas não em dias ensolarados, exceto pelo aumento nos primeiros 10 min de exposição à luz solar plena. Para uma dada fluência, $\mathrm{F}_{\mathrm{m}}$ foi menor nos dias ensolarados. A recuperação da fotoinibição foi similar em ambos os ambientes de luz. Apesar de a fluência de fótons ser o fator preponderante na determinação do grau de fotoinibição, a nebulosidade ameniza o efeito fotoinibitório da irradiância.

Palavras-chave: Amazônia, fotossistema II funcional, fluência de fótons, fluorescência inicial, qualidade de luz
\end{abstract}

\section{INTRODUCTION}

Sudden exposure to high light intensity, as it might occur in gaps of tropical forests, may lead to photoinhibition of photosynthesis of saplings and seed- lings (Krause \& Winter, 1996). Shade tolerant species are more susceptible to photoinhibition than full sunlight-adapted species (Demmig-Adams \& Adams, 1992; Kitao et al., 2000a). The term photoinhibition describes the slowly reversible and light-dependent re- 
duction of the photochemical efficiency when plants are exposed to light intensities above values that can be used for photochemical reactions (Long et al., 1994). Manwood (Minquartia guianensis Aubl.) and other shade tolerant species have a low capacity for photosynthesis at a saturating light intensity (Marenco \& Vieira, 2005) and a low capacity for $\mathrm{D}_{1}$ protein degradation, and can accumulate a high population of nonfunctional photosystems II (Anderson et al., 1997; Krause et al., 1999). Under sunny conditions, sunlit leaves experience light saturation and the energy of additional photons not used in carbon assimilation may lead to photoinhibition (Choudhury \& Behera, 2001; Demmig-Adams \& Adams, 2006).

Cloudiness may influence photosynthesis by affecting photon fluence (Graham et al., 2003; Costa \& Marenco, 2007). Clouds reduce both the intensity of ultraviolet (UV) irradiance reaching the Earth surface (Madronich et al., 1998) and the vapour pressure deficit, VPD (Gu et al., 1999; Roderick et al., 2001). Photosynthesis tends to be higher at low VPD (Marenco et al., 2006), whereas the efficiency of the PSII may decrease by UV irradiance, particularly in shade-adapted plants (Krause et al., 1999; 2003). Thus, the aim of this study was to determine the effect of cloud cover on photoinhibition and fluorescence characteristics of manwood saplings, and the recovery from photoinhibition at low light intensity.

\section{MATERIAL AND METHODS}

Three-year-old and 0.3-m tall saplings of manwood (Minquartia guianensis Aubl., Olacaceae), were grown in plastic bags ( $3 \mathrm{~L}$ ) beneath a small natural forest located in Manaus, AM, Brazil (030' S, $\left.59^{\circ} 59^{\prime} \mathrm{W}\right)$. The substrate consisted of soil from a natural forest collected from the first $20-\mathrm{cm}$ layer $(\mathrm{pH}$ 5.5 and clayey texture). During the growing period, plants were watered daily. The maximum irradiance beneath the canopy of adult trees was about $20 \mu \mathrm{mol}$ $\mathrm{m}^{-2} \mathrm{~s}^{-1}$ at midday.

The initial (the signal emitted when the PSII reaction centers are open, $\mathrm{F}_{\mathrm{o}}$ ) and maximum fluorescence (the signal emitted when all the PSII reaction centers are closed, $\mathrm{F}_{\mathrm{m}}$ ), and the $\mathrm{F}_{\mathrm{v}} / \mathrm{F}_{\mathrm{m}}$ ratio (a direct measure of the efficiency of the PSII primary photochemistry) were measured in intact leaves using a portable fluorometer (PEA, MK2, 9600, Hansatech, Norfolk, UK). Before measurements the leaves were darkadapted for $15 \mathrm{~min}$. A light saturation pulse $(3000 \mu \mathrm{mol}$ $\mathrm{m}^{-2} \mathrm{~s}^{-1}$ ) was given over an area of 4-mm-diameter with an array of 6 LED's $(\lambda$ max. $650 \mathrm{~nm}$ ). The population of functional photosystems II (PSII) was calculated after Lee et al. (2001) from the values of $F_{0}$ and
$\mathrm{F}_{\mathrm{m}}$ as follows: $\alpha\left(1 / \mathrm{F}_{\mathrm{o}}-1 / \mathrm{F}_{\mathrm{m}}\right)$; where $\alpha$ denotes a fitting constant used to normalize for a maximum population of functional PSII (100\%) in $12 \mathrm{~h}$ dark-adapted leaves of non-stressed plants.

Plants were exposed to full irradiance on clear days or under overcast conditions. On clear days, they were exposed to $10 \mathrm{~min}\left(\mathrm{~T}_{10}\right), 45 \mathrm{~min}\left(\mathrm{~T}_{45}\right)$, and 90 $\min \left(\mathrm{T}_{90}\right)$, whereas on cloudy days for $120 \mathrm{~min}\left(\mathrm{~T}_{120}\right)$, $300 \mathrm{~min}\left(\mathrm{~T}_{300}\right)$, and $420 \mathrm{~min}\left(\mathrm{~T}_{420}\right)$. Control plants were kept at low irradiance (10 to $20 \mu \mathrm{mol} \mathrm{m}^{-2} \mathrm{~s}^{-1}$ or in the dark at night). Following irradiance treatments, recovery from photoinhibition (measured as the $\mathrm{F}_{\mathrm{v}} / \mathrm{F}_{\mathrm{m}}$ ratio) at low light (10-20 $\mu \mathrm{mol} \mathrm{m}^{-2} \mathrm{~s}^{-1}$ or in the dark, at night) was monitored at $0.25,0.50,1,2,3,5$, and $48 \mathrm{~h}$ on 15 -min dark-adapted leaves.

Photosynthetic photon flux density (PFD) was measured with a quantum sensor (LI-191 SA, Li-Cor, Lincoln, NE, USA) connected to datalogger (LI-1000; $\mathrm{Li}$-Cor). Fluence $\left(\mathrm{mol} \mathrm{m}^{-2}\right)$ was calculated as the product of irradiance and time of illumination. Data were analysed using the standard error of means.

\section{RESULTS AND DISCUSSION}

In comparison with control plants kept at low light, $\mathrm{F}_{0}$ increased (28\%) with photon fluence in saplings subjected to irradiance treatments on cloudy days (Figure 1A). On clear days, however, $\mathrm{F}_{0}$ was unaffected by irradiance, except for a sharp rise (21\%) during the first $10 \mathrm{~min}$ of exposure $(0.8 \mathrm{~mol}$ (photon) $\mathrm{m}^{-2}$ ) to full sunlight (Figure 1A). The rise in $\mathrm{F}_{0}$ could be a result of any of the following reasons: (1) a functional dissociation of the antenna complex from the PSII reaction center, such as that occurring during heat damage (Armond et al., 1978; Kitao et al., 2000b); (2) Damage to the $\mathrm{D}_{1}$ protein of the PSII reaction center, as impairment of electron transport from $Q_{A}$ to $Q_{B}$ may result in a rise in $F_{0}$ (Gilmore et al., 1996), and (3) Chlororespiration, a nonphotochemical reduction of $Q_{A}$ by reducing equivalents supplied in the dark from a stromal pool of NAD(P)H (Peltier \& Cournac, 2002).

The first hypothesis does not appear to be plausible to explain the observed rise in $\mathrm{F}_{0}$ on cloudy days because leaf temperature is often low under cloud cover. The impairment of electron transport from $Q_{A}$ to $Q_{B}$ due to $D_{1}$ protein damage is a reasonable explanation for the increase in $\mathrm{F}$, because damage to the $\mathrm{D}_{1}$ protein may occur at any light intensity (Tyystjärvi \& Aro, 1996). Finally, the effect of chlororespiration cannot be ruled out, as the addition of exogenous $\mathrm{NAD}(\mathrm{P}) \mathrm{H}$ to chloroplasts induces an increase in $\mathrm{F}_{\mathrm{o}}$ as a result of electron donation to $\mathrm{Q}_{\mathrm{A}}$ (Mills et al., 1979; Corneille et al., 1998). This is an attractive hypothesis as plastoquinones may remain reduced in the dark for 

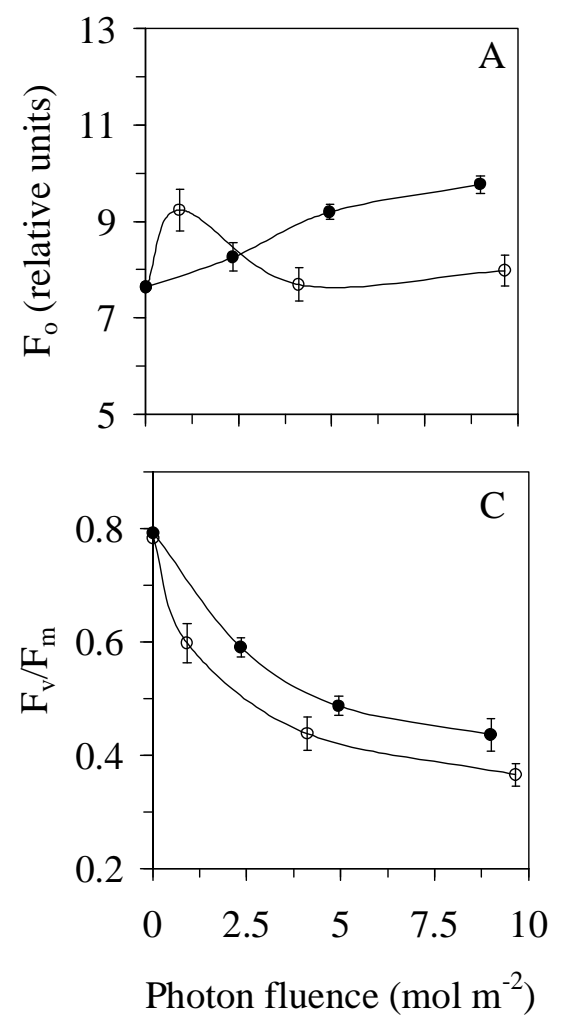
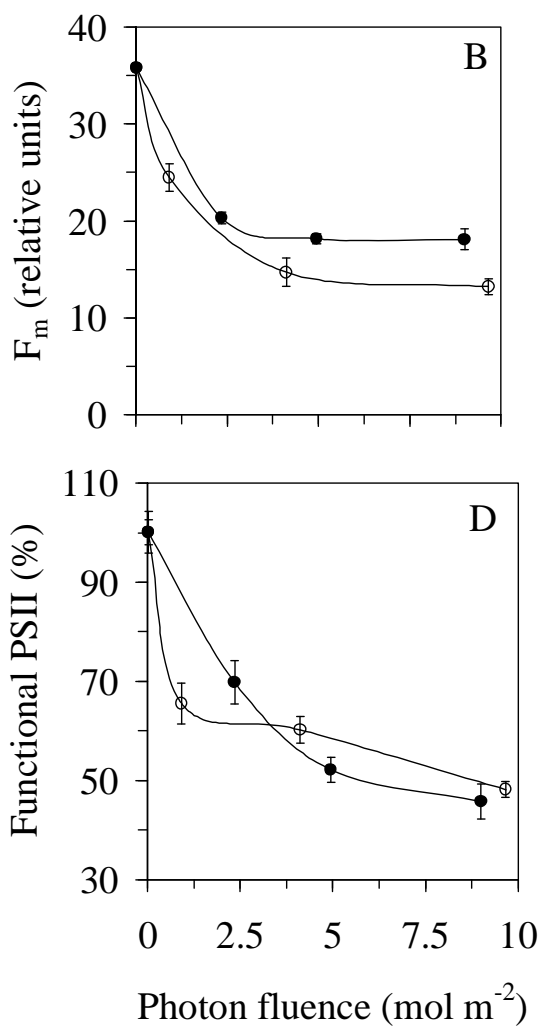

Figure 1 - Effect of photon fluence on fluorescence characteristics (A-C) and the population of functional PSII (D) in saplings of manwood (Minquartia guianensis). Plants received full irradiance treatments on clear (open symbols) or cloudy days (closed symbols). Each point represents the mean of five plants and three leaves per plant. Standard error is shown when larger than the symbol. ( $F_{0}=$ initial fluorescence; $F_{m}=$ maximum fluorescence; $F_{v}=$ variable fluorescence $=F_{m}-F_{0}$ ).

several hours following a period of illumination (Groom et al., 1993). Changes in $\mathrm{F}_{\mathrm{o}}$ in plants subjected to high irradiance are similar to those observed by Dias \& Marenco (2006; 2007). They explained the constancy or decrease in $\mathrm{F}_{\mathrm{o}}$ under full sunlight on the ground of a severe damage to the photochemical apparatus, for example damage to the water splitting complex of the PSII reaction center at high light intensities. Increasing photon fluence exacerbates photoinhibition due to damage to proteins of the PSII reaction center, particularly the $\mathrm{D}_{1}$ protein and under prolonged light exposure subunits of the oxygen evolving complex are also affected (Bertamini et al., 2004). Plants transferred from deep shade to full sunlight had lower growth rates than those switched from full shade to partially shade conditions because of PSII damage in the open (Oberbauer \& Strain, 1985). These authors suggest that in the event of a large treefall gap in a dense forest, understory plants may require a substantial period of acclimation before they respond to an increase in irradiance.

Compared with control plants, $\mathrm{F}_{\mathrm{m}}$ always declined after the exposure to irradiance in both light environments (Figure 1B), but the reduction in $\mathrm{F}_{\mathrm{m}}$ was greater on sunny days than under cloudy conditions. The decrease in $\mathrm{F}_{\mathrm{m}}$ can mainly be attributed to damage to the $\mathrm{D}_{1}$ protein because the pool of xanthophyll pigments, involved in the xanthophyll cycle is rather low in shade-adapted plants (Demmig-Adams \& Adams, 1992; 1996). Although there is a positive correlation between the extent of photoinhibition and the amount of zeaxanthin formed during plant exposure to high irradiance (Thiele et al., 1998), $\mathrm{D}_{1}$ protein inactivation is probably the prevailing mechanism leading to photoinhibition in understory shade-acclimated leaves abruptly exposed to full sunlight when new gaps open up (Mulkey \& Pearcy, 1992). Cloudiness in this study reduced the effect of full sunlight on $\mathrm{F}_{\mathrm{m}}$ at high fluences (Figure 1B), perhaps by reducing the amount of UV radiation reaching the plant (Madronich et al., 1998), as UV radiation exacerbates the photoinhibitory effect of solar radiation (Krause et al., 1999; 2003).

The $\mathrm{F}_{\mathrm{v}} / \mathrm{F}_{\mathrm{m}}$ ratio declined with fluence of photons in all treatments, with lower values being observed in plants exposed to light on clear days (Figure 1C). The fall in $\mathrm{F}_{\mathrm{v}} / \mathrm{F}_{\mathrm{m}}$ occurred irrespective of the trend followed by $\mathrm{F}_{\mathrm{o}}$, indicating that the $\mathrm{F}_{\mathrm{v}} / \mathrm{F}_{\mathrm{m}}$ ratio was determined primarily by $\mathrm{F}_{\mathrm{m}}$ values. Thus, the longer the ex- 
posure time to full sunlight the greater the decrease in the potential photochemical efficiency. The $\mathrm{F}_{\mathrm{v}} / \mathrm{F}_{\mathrm{m}}$ ratio fell $54 \%$ in saplings submitted to $\mathrm{T}_{90}$ on sunny days; that is, in plants exposed to a fluence of $9.7 \mathrm{~mol} \mathrm{~m}^{-2}$ (Figure 1C). However, a lower decrease in $\mathrm{F}_{\mathrm{v}} / \mathrm{F}_{\mathrm{m}}$ (46\%) was observed in plants subjected to a similar fluence $\left(9 \mathrm{~mol} \mathrm{~m}^{-2}, \mathrm{~T}_{420}\right.$ ) on cloudy days. Reduction of the $\mathrm{F}_{\mathrm{v}} / \mathrm{F}_{\mathrm{m}}$ ratio, as observed in this study after plant exposure to high light intensity, is a well-documented phenomenon and is a measure of the decline of the potential maximum quantum yield of PSII (Björkman \& Demmig, 1987; Genty et al., 1989). Indeed, a decline in $\mathrm{F}_{\mathrm{v}} / \mathrm{F}_{\mathrm{m}}$ suggests that the integrity of the PSII was altered, and indicates photoinhibition of photosynthesis (Long et al., 1994).

For a given intensity of irradiance reaching the leaf surface, $\mathrm{F}_{\mathrm{v}} / \mathrm{F}_{\mathrm{m}}$ values were lower on clear days than under overcast conditions (Figure 1C). This suggests that in addition to its effect on light attenuation, changes in light quality due to cloudiness may also have a mitigating effect of photoinhibition. The attenuating effect of cloudiness on photoinhibition could be associated with a reduced proportion of UV radiation in the solar spectrum on cloudy days (Madronich et al., 1998; Calbó et al., 2005). Krause et al. (1999) reported that photoinhibition is less severe in UV-decreased sunlight, particularly in shade-adapted plants (Krause et al., 2003). As the extent of photoinhibition depends on the synergistic effects of leaf temperature and irradiance, periods of cloudiness may reduce photoinhibition of plants growing in gaps (Mulkey \& Pearcy, 1992). Not surprisingly, it has been reported that on cloudy days, $\mathrm{F}_{\mathrm{v}} / \mathrm{F}_{\mathrm{m}}$ values may remain unchanged or even increase (Flexas et al., 2000).

Decline in $F_{m}$ and $F_{v} / F_{m}$ with photon fluence can be separated in two phases. The first phase is represented by a sharp drop, particularly in $\mathrm{F}_{\mathrm{m}}$, between 0 and $5 \mathrm{~mol} \mathrm{~m}^{-2}$ (Figure 1B-C). At higher fluences, a gradual decline in $\mathrm{F}_{\mathrm{m}}$ and $\mathrm{F}_{\mathrm{v}} / \mathrm{F}_{\mathrm{m}}$ was observed (second phase). In this phase $\mathrm{F}_{\mathrm{m}}$ tended to level off. Decline in $\mathrm{F}_{\mathrm{m}}$ and $\mathrm{F}_{\mathrm{v}} / \mathrm{F}_{\mathrm{m}}$ with photon fluence confirms the hypothesis of Anderson et al. (1997), who demonstrated that a reduction of photochemical efficiency depends on the amount of absorbed photons. Thus, photoinactivation of PSII is a light dosage effect with an increase in the amount of light energy absorbed leading to a decline in $\mathrm{F}_{\mathrm{m}}$, irrespective of exposure time or light intensity. The precipitously fall (first phase) in $\mathrm{F}_{\mathrm{m}}$, from 0 to $3 \mathrm{~mol} \mathrm{~m}^{-2}$ (Figure 1B) may be related to photoprotection processes. This phase probably involves the activation of the xanthophyll cycle whereby the excess of energy is dissipated as heat (DemmigAdams \& Adams, 1992). The second phase (gradual decline in $\mathrm{F}_{\mathrm{m}}$ and $\mathrm{F}_{\mathrm{v}} / \mathrm{F}_{\mathrm{m}}$, Figure $1 \mathrm{~B}-\mathrm{C}$ ) is not clearly understood and does not appear to be associated with changes in the zeaxanthin pool (Lichtenthaler et al., 1992).

The content of functional PSII $(y)$ was calculated as: $y$ (\% of control plants $)=968.20\left(1 / \mathrm{F}_{0}-1 /\right.$ $\mathrm{F}_{\mathrm{m}}$ ) (Figure 1D). In this figure, a sharp decline of functional PSII complexes may be observed at low fluences in plants subjected to full irradiance on clear days, but at higher fluences, cloud cover had no clear effects on PSII photoinactivation, perhaps because at higher fluences photoinhibited PSII reaction centers may confer, as they accumulated, additional protection of the remaining but still functional PSII complexes, as suggested by Öquist et al. (1992).

Compared with control plants, $\mathrm{F}_{\mathrm{o}}$ increased during the first six hours while recovering from photoinhibition at low light, particularly at low to moderate photon fluence on cloudy days (Figure 2A-B). An increase in $\mathrm{F}_{\mathrm{o}}$ indicates a less severe damage to the PSII, and suggests little or no damage to the water splitting complex (Bertamini et al., 2004). Thus, recovery from photoinhibition (restoration of the $F_{v} / F_{m}$ values) took less time in irradiance treatments that reached higher $\mathrm{F}_{\mathrm{o}}$ values following the light treatments. Recovery from photoinhibition involves the reactivation of the PSII reaction centers involving $\mathrm{D}_{1}$ protein turnover (Aro et al., 1993; Xu \& Wu, 1996). Depending on the amount of time required to restore $\mathrm{F}_{\mathrm{v}} / \mathrm{F}_{\mathrm{m}}$ ratios at low light, photoinhibition can be dynamic or chronic (Osmond, 1994). Dynamic photoinhibition, as observed for $T_{10}$ has been associated with down-regulation of PSII activity (Osmond, 1994). Chronic photoinhibition, such as observed in this study at high fluences (e.g. $\mathrm{T}_{300}, \mathrm{~T}_{420}$ ), is slowly reversible is characterized by a slow recovery of the maximum potential quantum yield of PSII at low light (Figure 2H-I).

$\mathrm{F}_{\mathrm{m}}$ did not restore to values observed in control plants within $48 \mathrm{~h}$ at low light (Figure 2D-F). This is not surprising, as recovery from photoinhibition may often take a few days in severely photoinhibited plants (Mulkey \& Pearcy, 1992; Dias \& Marenco, 2006; 2007). Finally, although photon fluence is the most important factor determining the extent of photoinhibition, cloudiness may alleviate the photoinhibitory effect of irradiance, perhaps because clouds generally reduce surface ultraviolet irradiance, thereby relieving the effect of irradiance on photoinhibition of shade-adapted plants. These results may be important taking into account that the increased rate of deforestation of the Amazonian forest may reduce cloudiness in some parts of the Amazon region (Fearnside, 1995), which could affect photosynthesis and growth of understory shade-acclimated plants suddenly exposed to full sunlight. 

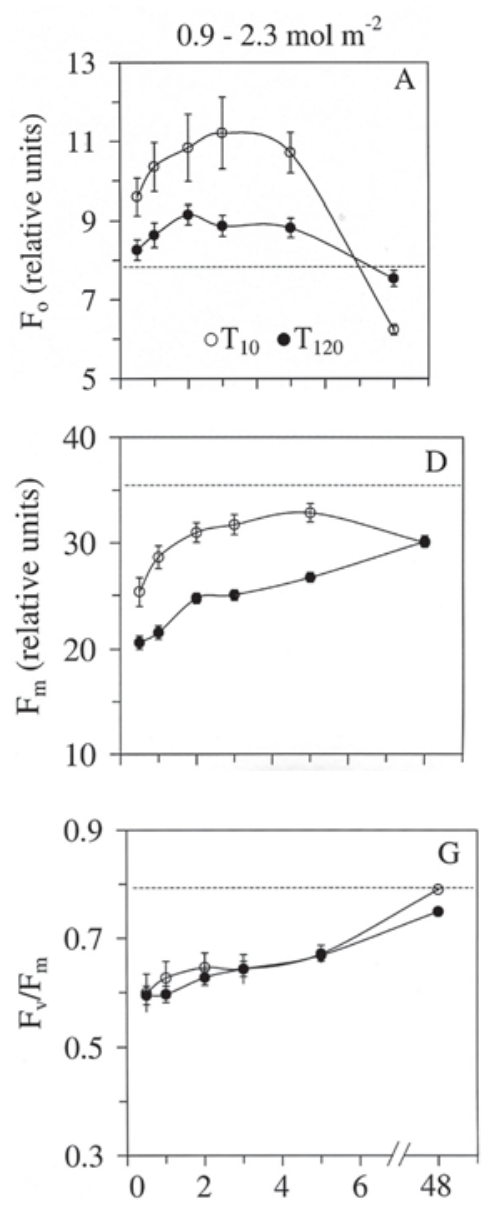
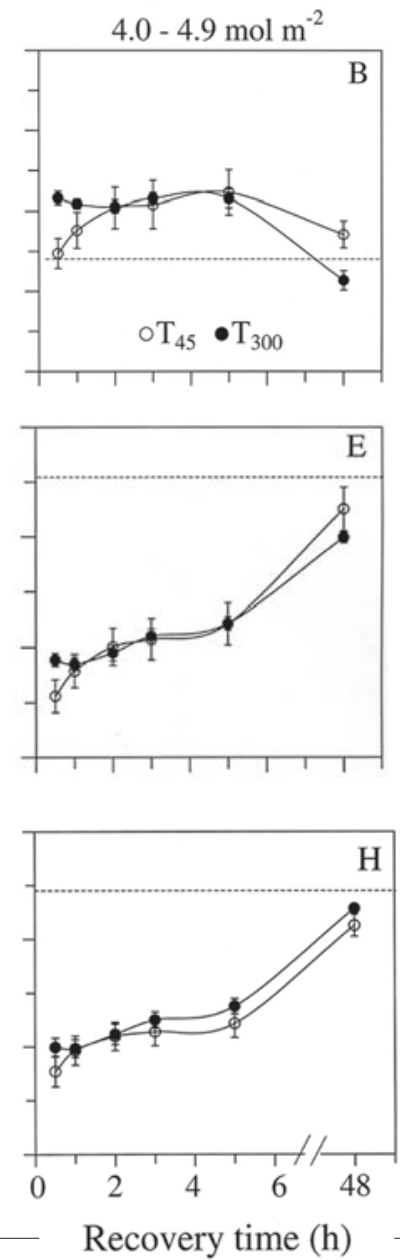
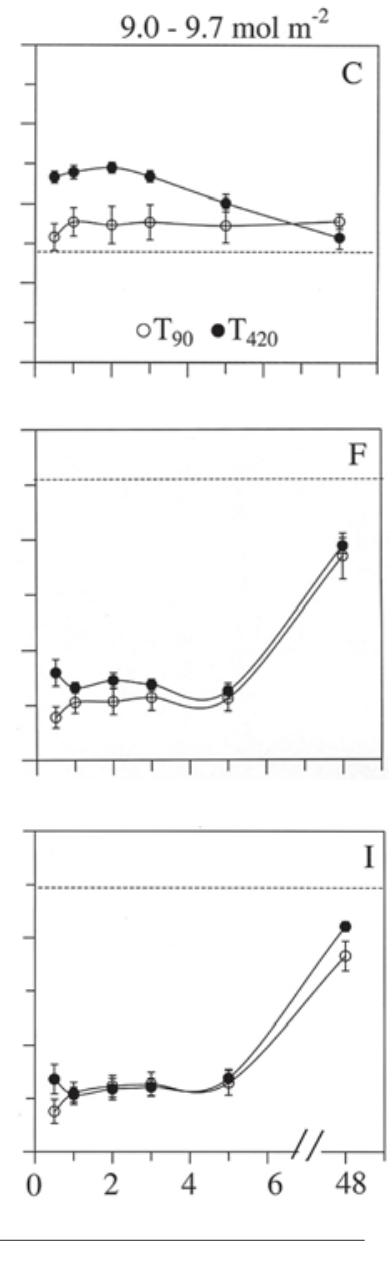

Figure 2 - Effect of photon fluence on fluorescence characteristics in saplings of manwood (Minquartia guianensis) during recovery at low irradiance. Plants were exposed to full irradiance on sunny $(\mathrm{O})$ or cloudy days $(\bullet)$. A, D and G: fluence of 0.9 to $2.3 \mathrm{~mol} \mathrm{~m}^{-2}\left(\mathrm{~T}_{10}, \mathrm{~T}_{120}\right)$; B, E and H: fluence of 4.0 to $4.9 \mathrm{~mol} \mathrm{~m}^{-2}\left(\mathrm{~T}_{45}, \mathrm{~T}_{300}\right)$; C, F and I: fluence of 9.0 to $9.7 \mathrm{~mol} \mathrm{~m}^{-2}\left(\mathrm{~T}_{90}, \mathrm{~T}_{420}\right)$. Dashed lines indicate values for control plants. Each point represents the mean of five plants and three leaves per plant. Standard error is shown when larger than the symbol. $\left(F_{o}=\right.$ initial fluorescence; $F_{m}=$ maximum fluorescence; $F_{v}=$ variable fluorescence $=\mathrm{F}_{\mathrm{m}}-\mathrm{F}_{\mathrm{o}}$ ).

\section{ACKNOWLEDGEMENTS}

This research was supported by MCT/INPA and FAPEAM-PIPT 1084-04. The authors thank CAPES and CNPq for the scholarships awarded.

\section{REFERENCES}

ANDERSON, J.M.; PARK, Y.-I.; CHOW, W.S. Photoinactivation and photoprotection of photosystem II in nature. Physiologia Plantarum, v.100, p.214-223, 1997.

ARMOND, P.A.; SCHREIBER U.; BJORKMAN, O. Photosynthetic acclimation to temperature in the desert shrub, Larrea divaricata. II. Light-harvesting efficiency and electron transport. Plant Physiology, v.61, p.411-415, 1978.

ARO, E.-M.; McCAFFERY, S.; ANDERSON, J.M. Photoinhibition and D1 protein degradation in peas acclimated to different growth irradiances. Plant Physiology, v.103, p.835-843, 1993.

BERTAMINI, M.; MUTHUCHELIAN, K.; NEDUNCHEZHIAN, N. Photoinhibition of photosynthesis in sun and shade grown leaves of grapevine (Vitis vinifera L.). Photosynthetica, v.42, p.7-14, 2004.
BJÖRKMAN, O.; DEMMIG, B. Photon yield of $\mathrm{O}_{2}$ evolution and chlorophyll fluorescence characteristics at $77 \mathrm{~K}$ among vascular plants of diverse origins. Planta, v.170, p.489-504, 1987.

CALBÓ, J.; PAGÈS, D.; GONZÁLEZ, J.-A. Empirical studies of cloud effects on UV radiation: a review. Review of Geophysics, v.43, 2005. DOI 10.1029/2004R G000155.

CHOUDHURY, N.K.; BEHERA, R.K. Photoinhibition of photosynthesis: Role of carotenoids in photoprotection of chloroplast constituents. Photosynthetica, v.39, p.481-488, 2001.

CORNEILLE, S.; COURNAC, L.; GUEDENEY, G.; HAVAUX, M.; PELTIER, G. Reduction of the plastoquinone pool by exogenous NADH and NADPH in higher plant chloroplasts characterization of a NAD(P)H-plastoquinone oxidoreductase activity. Biochimica et Biophysica Acta, v.1363, p.59-69, 1998.

COSTA, G.F.; MARENCO, R.A. Fotossíntese, condutância estomática e potencial hídrico foliar em árvores jovens de andiroba (Carapa guianensis). Acta Amazônica, v.37, p.229234, 2007.

DEMMIG-ADAMS, B.; ADAMS, W.W. III. Photoprotection and other responses of plants to high light stress. Annual Review of Plant Physiology and Plant Molecular Biology, v.43, p.599-626, 1992. 
DEMMIG-ADAMS, B.; ADAMS, W.W. III The role of xanthophyll cycle carotenoids in the protection of photosynthesis. Trends in Plant Science, v.1, p.21-26, 1996.

DEMMIG-ADAMS, B.; ADAMS, W.W. III Photoprotection in an ecological context: the remarkable complexity of thermal energy dissipation. New Phytologist, v.172, p.11-21, 2006.

DIAS, D.P.; MARENCO, R.A. Photoinhibition of photosynthesis in Minquartia guianensis and Swietenia macrophylla inferred by monitoring the initial fluorescence. Photosynthetica, v.44, p.235-240, 2006.

DIAS, D.P.; MARENCO, R.A. Fotossíntese e fotoinibição em mogno e acariquara em função da luminosidade e temperatura foliar. Pesquisa Agropecuária Brasileira, v.42, p.305-311, 2007.

FEARNSIDE, P.M. Potential impacts of climatic change on natural forests and forestry in Brazilian Amazonia. Forest Ecology and Management, v.78, p.51-70, 1995.

FLEXAS, J.; BRIANTAIS, J.-M.; CEROVIC, Z.; MEDRANO, H.; MOYA, I. Steady-state and maximum chlorophyll fluorescence responses to water stress in grapevine leaves: a new remote sensing system. Remote Sensing of Environment, v.73, p.283-297, 2000 .

GENTY, B.; BRIANTAIS, J.; BAKER, N. The relationship between the quantum yield of photosynthetic electron transport and quenching of chlorophyll fluorescence. Biochimica et Biophysica Acta, v.990, p.87-92, 1989.

GILMORE, A.M.; HAZLETT, T.L.; DEBRUNNER, P.G.; GOVINDJEE. Comparative time-resolved photosystem II chlorophyll $a$ fluorescence analyses reveal distinctive differences between photoinhibitory reaction center damage and xanthophyll cycle-dependent energy dissipation. Photochemistry and Photobiology, v.64, p.552-563, 1996.

GRAHAM, E.A.; MULKEY, S.S.; KITAJIMA, K.; PHILLIPS, N.G.; WRIGHT, S.J. Cloud cover limits net $\mathrm{CO}_{2}$ uptake and growth of a rainforest tree during tropical rainy seasons. Proceedings of the National Academy of Sciences of the USA, v.100, p.572-576, 2003.

GROOM, Q.J.; KRAMER, D.M.; CROFTS, A.R.; ORT, D.R. The non-photochemical reduction of plastoquinone in leaves. Photosynthesis Research, v.36, p.205-215, 1993.

GU, L.; FUENTES, J.D.; SHUGART, H.H.; STAEBLER, R.M.; BLACK, T.A. Responses of net ecosystem exchanges of carbon dioxide to changes in cloudiness: Results from two North American deciduous forests. Journal of Geophysical Research, v.104, p.31421-31434, 1999.

KITAO, M.; LEI, T.T.; KOIKE, T.; TOBITA, H.; MARUYAMA, Y. Susceptibility to photoinhibition of three deciduous broadleaf tree species with different successional traits raised under various light regimes. Plant, Cell and Environment, v.23, p.81-89, 2000a.

KITAO, M.; LEI, T.T.; KOIKE, T.; TOBITA, H.; MARUYAMA, Y.; MATSUMOTO, Y.; ANG, L.H. Temperature response and photoinhibition investigated by chlorophyll fluorescence measurements for four distinct species of dipterocarp trees. Physiologia Plantarum, v.109, p.284-290, 2000b.

KRAUSE, G.H.; WINTER, K. Photoinhibition of photosynthesis in plants growing in natural tropical forest gaps. A chlorophyll fluorescence study. Botanica Acta, v.109, p.456-462, 1996.

KRAUSE, G.H.; SCHMUDE, C.; GARDEN, H.; KOROLEVA, O.Y.; WINTER, K. Effects of solar ultraviolet radiation on the potential efficiency of photosystem II in leaves of tropical plants. Plant Physiology, v.121, p.1349-1358, 1999.

KRAUSE, G.H.; GALLE, A.; GALLE, R.; GADEMANN, R.; WINTER, K. Capacity of protection against ultraviolet radiation in sun and shade leaves of tropical forest plants. Functional Plant Biology, v.30, p.533-542, 2003.

LEE, H.-Y.; HONG, Y.-N.; CHOW, W.S. Photoinactivation of photosystem II complexes and photoprotection by nonfunctional neighbours in Capsicum annun L. leaves. Planta, v.212, p.332-342, 2001.
LICHTENTHALER, H.K.; BURKART, S.; SCHINDLER, C.; STOBER, F. Changes in photosynthetic pigments and in vivo chlorophyll fluorescence parameters under photoinhibitory growth conditions. Photosynthetica, v.27, p.343-353, 1992.

LONG, S.P.; HUMPHRIES, S.; FALKOWSKI, P.G. Photoinhibition of photosynthesis in nature. Annual Review of Plant Physiology and Plant Molecular Biology, v.45, p.633-662, 1994.

MADRONICH, S.; McKENZIE, R.L.; BJORN, L.O.; CALDWELL, M.M. Changes in biologically active ultraviolet radiation reaching the Earth's surface. Journal of Photochemistry and Photobiology, v.46, p.5-19, 1998.

MARENCO, R.A.; VIEIRA, G. Specific leaf area and photosynthetic parameters of tree species in the forest understorey as a function of the microsite light environment in central Amazonia. Journal of Tropical Forest Science, v.17, p.265-278, 2005.

MARENCO, R.A.; SIEBKE, K.; FARQUHAR, G.D.; BALL, M.C. Hydraulically based stomatal oscillations and stomatal patchiness in Gossypium hirsutum. Functional Plant Biology, v.33, p.1103-1113, 2006.

MILLS, J.D.; CROWTHER, D.; SLOVACEK, R.E.; HIND, G.; McCCARTY, R.E. Electron transport pathways in spinach chloroplasts. Reduction of the primary acceptor of photosystem II by reduced nicotinamide adenine dinucleotide phosphate in the dark. Biochimica et Biophysica Acta, v.547, p.127-137, 1979.

MULKEY, S.S.; PEARCY, R.W. Interactions between acclimation and photoinhibition of photosynthesis of a tropical forest understorey herb, Alocasia macrorrhiza, during simulated canopy gap formation. Functional Ecology, v.6, p.719-729, 1992.

OBERBAUER, S.F.; STRAIN, B.R. Effects of light regime on the growth and physiology of Pentaclethra macroloba (Mimosaceae) in Costa Rica. Journal of Tropical Ecology, v.1, p.303-320, 1985.

ÖQUIST, G.; CHOW, W.S.; ANDERSON, J.M. Photoinhibition of photosynthesis represents a mechanism for the long-term regulation of photosystem II. Planta, v.186, p.450-460, 1992.

OSMOND, C.B. What is photoinhibition? Some insights from comparison of shade and sun plants. In: BAKER, R.R.; BOWYER, J.R., (Ed.). Photoinhibition of photosynthesis: from molecular mechanisms to the field. Oxford: Bios Scientific Publications, 1994. cap.1, p.1-24.

PELTIER, G.; COURNAC, L.: Chlororespiration. Annual Review of Plant Biology, v.53, p.523-550, 2002.

RODERICK, M.L.; FARQUHAR, G.D.; BERRY, S.L.; NOBLE, I.R. On the direct effect of clouds and atmospheric particles on the productivity and structure of vegetation. Oecologia, v.129, p.21-30, 2001.

THIELE, A.; KRAUSE, G.H.; WINTER, K. In situ study of photoinhibition of photosynthesis and xanthophyll cycle activity in plants growing in natural gaps of the tropical forest. Australian Journal of Plant Physiology, v.25, p.189-195, 1998.

TYYSTJÄRVI, E.; ARO, E.M. The rate constant of photoinhibition, measured in lincomycin-treated leaves, is directly proportional to light intensity. Proceedings of the National Academy of Sciences of the USA, v.93, p.2213$2218,1996$.

XU, D.Q.; WU, S. Three phases of dark-recovery course from photoinhibition resolved by the chlorophyll fluorescence analysis in soybean leaves under field conditions. Photosynthetica, v.32, p.417-423, 1996.

Received February 12, 2007

Accepted August 14, 2007 